\title{
Speckle tracking: distinction of physiologic from pathologic LVH?
}

\author{
E. E. van der Wall $\cdot$ V. Delgado $•$ E. R. Holman • \\ J. J. Bax
}

Received: 12 August 2010/Accepted: 13 August 2010/Published online: 24 August 2010

(C) The Author(s) 2010. This article is published with open access at Springerlink.com

Over the past years, echocardiography and magnetic resonance imaging (MRI) have become important imaging modalities in patients with a broad spectrum of cardiomyopathies [1-20]. Both imaging modalities have been shown to play a pivotal role in the accurate evaluation of left ventricular function particularly in patients with ischemic heart disease and different forms of cardiomyopathy [21-36]. These methods are needed to accurately identify and characterize patients with various manifestations of left ventricular hypertrophy (LVH) [37-49]. The important question should be resolved whether training-induced LVH in athletes is a physiological rather than a pathophysiological phenomenon [50-57]. In a meta-analysis using MRI, involving 59 studies and 1,451 athletes (both endurance-trained and strength-trained athletes), it was reported that the athlete's heart demonstrated normal systolic and diastolic cardiac function, implying that training-induced LVH in athletes is predominantly a physiological phenomenon [58]. With respect to echocardiography, two-dimensional strain has become a novel method to measure strain from standard two-

Editorial comment to the article of Butz et al. (10.1007/s10554-010-9665-5).

E. E. van der Wall $(\bowtie) \cdot$ V. Delgado .

E. R. Holman · J. J. Bax

Department of Cardiology, Leiden University Medical Center, P.O. Box 9600, Leiden, The Netherlands

e-mail: e.e.van_der_wall@lumc.nl dimensional echocardiographic images by speckle tracking. Speckle tracking offers the advantage of being less angle-dependent and more reproducible than conventional Doppler-derived strain [59-61]. This echocardiographic imaging technique allows quantification of global and regional myocardial deformation on the basis of tracking of acoustic markers from frame-to-frame.

In the current issue of the International Journal of Cardiovascular Imaging, Butz et al. [62] questioned whether two-dimensional strain assessed by speckle tracking was useful as an additional tool in differentiating pathologic from physiologic LVH in high-level athletes. The objective of the study was to identify and characterize global and regional function abnormalities in patients with pathological left ventricular hypertrophy $(\mathrm{LVH})$ caused by non-obstructive hypertrophic cardiomyopathy (HCM), in high-level athletes, and in healthy controls. The authors consecutively studied 53 subjects consisting of 15 patients with HCM and 20 competitive top-level athletes. A control group of 18 sedentary normal subjects was studied by standard echocardiography according to standard guidelines. Global longitudinal strain and regional peak systolic strain were assessed by two-dimensional strain in the apical four-chamber view. It turned out that all components of strain were significantly reduced in patients with HCM when compared to athletes and control subjects. There was no significant difference between the strain values of the athletes and the control group, but in some segments the strain 
values of the control group were significantly higher than those in the athletes. A cut-off value of global longitudinal strain less than $-10 \%$ for the diagnosis of HCM resulted in a sensitivity of $80 \%$ and a specificity of $95 \%$. The combination of tissue Doppler imaging (averaged $\mathrm{S}^{\prime}, \mathrm{E}^{\prime}$ ) and global longitudinal strain cut-off values for the detection of pathologic LVH in HCM demonstrated a sensitivity of $100 \%$ and a specificity of $95 \%$. The authors concluded that speckle tracking is a new simple and rapid method to measure global longitudinal strain and peak systolic strain as components of systolic strain.

This novel and very interesting technique offers a unique approach to quantify global as well as regional systolic dysfunction, and might be used as new additional tool for the differentiation between physiologic and pathologic LVH. The present study is one of the first that used the combined and comprehensive tissue Doppler imaging analysis of systolic and early diastolic velocities of the lateral and septal mitral annulus as well as two-dimensional strain analysis for the differentiation between pathologic and physiologic LVH. The main results of this intriguing study show that global strain is significantly reduced in patients with HCM and that strain measurements can therefore be used for differentiation between pathologic and physiologic LVH. Especially, the combination of tissue Doppler imaging and two-dimensional strain assessment allows the differentiation of pathologic and physiologic LVH with acceptable sensitivity and specificity. This differentiation is extremely important in terms of clinical well-being, treatment and prognosis. In physiologic hypertrophy, such as in athletes, LVH reveals normal circumferential, radial, and longitudinal profiles possibly indicating that myocardial strain imaging might be useful as additional echocardiographic modality for the differentiation between athlete's heart and HCM. In pathologic hypertrophy, LVH appears to be associated with subendocardial fibrosis, which might be a potential mechanism for the failure of the hypertrophied myocardium in due time. In another study by the same group [63], peak systolic longitudinal strain of the basal septum and the opposite lateral wall was measured in addition to standard echocardiography in 88 consecutive patients with obstructive HCM who underwent a septal ablation procedure. Regional myocardial deformation was assessed quantitatively by speckle tracking. During a 12-month observation period, no patient had a severe adverse event. Reduction of left ventricular afterload by elimination of the outflow gradient following a successful septal ablation procedure resulted in improvement of systolic lateral longitudinal function in patients with obstructive HCM.

To summarize, two-dimensional strain analysis by echocardiography is a new simple, rapid, and reproducible method to measure systolic strain. Echocardiographic speckle tracking allows accurate quantitative assessment of regional myocardial deformation. As a result, the speckle tracking technique can be used as additional tool for (1) a comprehensive cardiac evaluation in subjects with physiologic hypertrophy versus pathologic hypertrophy, and (2) an appropriate assessment of the effects of therapy in patients with pathologic LVH.

Open Access This article is distributed under the terms of the Creative Commons Attribution Noncommercial License which permits any noncommercial use, distribution, and reproduction in any medium, provided the original author(s) and source are credited.

\section{References}

1. Ten Cate FJ (2009) Cardiomyopathies: a revolution in molecular medicine and cardiac imaging. Neth Heart J 17:456-457

2. Kleijn SA, Kamp O (2009) Clinical application of threedimensional echocardiography: past, present and future. Neth Heart J 17:18-24

3. Kamp O (2008) History of echocardiography in The Netherlands: 30 years of education and clinical applications. Neth Heart J 16:16-20

4. Nemes A, Geleijnse ML, van Geuns RJ et al (2008) Dobutamine stress MRI versus threedimensional contrast echocardiography: it's all black and white. Neth Heart J 16:217-218

5. Cramer MM, De Boeck BW (2007) Three-dimensional echocardiography and left bundle branch block: prime time in cardiology. Neth Heart J 15:87-88

6. Schuijf JD, Bax JJ, van der Wall EE (2007) Anatomical and functional imaging techniques: basically similar or fundamentally different? Neth Heart J 15:43-44

7. van der Wall, Vliegen HW, de Roos A, Bruschke AV (1995) Magnetic resonance imaging in coronary artery disease. Circulation 92:2723-2739

8. van der Wall EE, Siebelink HM, Bax JJ (2010) Evaluation of hypertrophic cardiomyopathy: new horizons for CMR? Neth Heart J 18:116-117

9. Holman ER, Buller VG, de Roos A et al (1997) Detection and quantification of dysfunctional myocardium by magnetic resonance imaging. A new three-dimensional method 
for quantitative wall-thickening analysis. Circulation 95: 924-931

10. van Rugge FP, van der Wall EE, Bruschke AV (1992) New developments in pharmacologic stress imaging. Am Heart J 124:468-485

11. van Rugge FP, Holman ER, van der Wall EE et al (1993) Quantitation of global and regional left ventricular function by cine magnetic resonance imaging during dobutamine stress in normal human subjects. Eur Heart J 14: 456-463

12. van Rugge FP, van der Wall EE, Spanjersberg SJ et al (1994) Magnetic resonance imaging during dobutamine stress for detection and localization of coronary artery disease Quantitative wall motion analysis using a modification of the centerline method. Circulation 90:127-138

13. Vliegen HW, Doornbos J, de Roos A, Jukema JW, Bekedam MA, van der Wall EE (1997) Value of fast gradient echo magnetic resonance angiography as an adjunct to coronary arteriography in detecting and confirming the course of clinically significant coronary artery anomalies. Am J Cardiol 79:773-776

14. Hoogendoorn LI, Pattynama PM, Buis B, van der Geest RJ, van der Wall EE, de Roos A (1995) Noninvasive evaluation of aortocoronary bypass grafts with magnetic resonance flow mapping. Am J Cardiol 75:845-848

15. Groenink M, Lohuis TA, Tijssen JG et al (1999) Survival and complication free survival in Marfan's syndrome: implications of current guidelines. Heart 82:499-504

16. Oosterhof T, van Straten A, Vliegen HW et al (2007) Preoperative thresholds for pulmonary valve replacement in patients with corrected tetralogy of Fallot using cardiovascular magnetic resonance. Circulation 116:545-551

17. van der Geest RJ, de Roos A, van der Wall EE, Reiber JH (1997) Quantitative analysis of cardiovascular MR images. Int J Card Imaging 13:247-258

18. van der Geest RJ, Niezen RA, van der Wall EE, de Roos A, Reiber JH (1998) Automated measurement of volume flow in the ascending aorta using MR velocity maps: evaluation of inter- and intraobserver variability in healthy volunteers. J Comput Assist Tomogr 22:904-911

19. van der Laarse A, Kerkhof PL, Vermeer F et al (1988) Relation between infarct size and left ventricular performance assessed in patients with first acute myocardial infarction randomized to intracoronary thrombolytic therapy or to conventional treatment. Am J Cardiol 61:1-7

20. van der Wall EE, Vliegen HW, de Roos A, Bruschke AV (1995) Magnetic resonance imaging in coronary artery disease. Circulation 92:2723-2739

21. Bavelaar-Croon CD, Kayser HW, van der Wall EE et al (2000) Left ventricular function: correlation of quantitative gated SPECT and MR imaging over a wide range of values. Radiology 217:572-575

22. Bleeker GB, Schalij MJ, Boersma E et al (2007) Relative merits of M-mode echocardiography and tissue Doppler imaging for prediction of response to cardiac resynchronization therapy in patients with heart failure secondary to ischemic or idiopathic dilated cardiomyopathy. Am J Cardiol 99:68-74

23. Bleeker GB, Bax JJ, Fung JW et al (2006) Clinical versus echocardiographic parameters to assess response to cardiac resynchronization therapy. Am J Cardiol 97:260-263
24. Bleeker GB, Holman ER, Steendijk P et al (2006) Cardiac resynchronization therapy in patients with a narrow QRS complex. J Am Coll Cardiol 48:2243-2250

25. Posma JL, Blanksma PK, van der Wall EE, Hamer HP, Mooyaart EL, Lie KI (1996) Assessment of quantitative hypertrophy scores in hypertrophic cardiomyopathy: magnetic resonance imaging versus echocardiography. Am Heart J 132:1020-1027

26. Vehmeijer JT, Christiaans I, van Langen IM et al (2009) Risk stratification for sudden cardiac death in hypertrophic cardiomyopathy: Dutch cardiologists and the care of mutation carriers. Neth Heart J 17:464-469

27. Christiaans I, Nannenberg EA, Dooijes D et al (2010) Founder mutations in hypertrophic cardiomyopathy patients in The Netherlands. Neth Heart J 18:248-254

28. ICIN working group on Heriditary Heart Diseases (2010) Genetic diagnostics and genetic counselling in Hypertrophic Cardiomyopathy (HCM). Neth Heart J 18:144-159

29. Pluim BM, Lamb HJ, Kayser HW, Leujes F et al (1998) Functional and metabolic evaluation of the athlete's heart by magnetic resonance imaging and dobutamine stress magnetic resonance spectroscopy. Circulation 97:666-67229

30. Pluim BM, Beyerbacht HP, Chin JC et al (1997) Comparison of echocardiography with magnetic resonance imaging in the assessment of the athlete's heart. Eur Heart J 18:1505-1513

31. Pluim BM, Chin JC, De Roos A et al (1996) Cardiac anatomy, function and metabolism in elite cyclists assessed by magnetic resonance imaging and spectroscopy. Eur Heart J 17:1271-1278

32. Schroeder J, Peterschroeder A, Vaske B et al (2009) Cardiac volumetry in patients with heart failure and reduced ejection fraction: a comparative study correlating multislice computed tomography and magnetic resonance tomography. Reasons for intermodal disagreement. Clin Res Cardiol 98:739-747

33. Germans T, Nijveldt R, Brouwer WP et al (2010) The role of cardiac magnetic resonance imaging in differentiating the underlying causes of left ventricular hypertrophy. Neth Heart J 18:135-143

34. Hoogsteen J, Hoogeveen A, Schaffers H, Wijn PF, van der Wall EE (2003) Left atrial and ventricular dimensions in highly trained cyclists. Int J Cardiovasc Imaging 19: 211-21734

35. Mihl C, Dassen WR, Kuipers H (2008) Cardiac remodelling: concentric versus eccentric hypertrophy in strength and endurance athletes. Neth Heart J 16:129-133

36. Nassenstein K, Breuckmann F, Lehmann N et al (2009) Left ventricular volumes and mass in marathon runners and their association with cardiovascular risk factors. Int J Cardiovasc Imaging 25:71-79

37. van der Wall EE, den Hollander W, Heidendal GA, Westera G, Majid PA, Roos JP (1981) Dynamic myocardial scintigraphy with $123 \mathrm{I}$-labeled free fatty acids in patients with myocardial infarction. Eur J Nucl Med 6:383-389

38. Braun S, van der Wall EE, Emanuelsson S, Kobrin I (1996) Effects of a new calcium antagonist, mibefradil (Ro 40-5967), on silent ischemia in patients with stable chronic angina pectoris: a multicenter placebo-controlled study. The mibefradil international study group. J Am Coll Cardiol 27:317-322 
39. de Roos A, Matheijssen NA, Doornbos J, van Dijkman PR, van Rugge PR, van der Wall EE (1991) Myocardial infarct sizing and assessment of reperfusion by magnetic resonance imaging: a review. Int J Card Imaging 7:133-138

40. van der Wall EE, van Dijkman PR, de Roos A et al (1990) Diagnostic significance of gadolinium-DTPA (diethylenetriamine penta-acetic acid) enhanced magnetic resonance imaging in thrombolytic treatment for acute myocardial infarction: its potential in assessing reperfusion. Br Heart J 63:12-17

41. van Rugge FP, Boreel JJ, van der Wall EE et al (1991) Cardiac first-pass and myocardial perfusion in normal subjects assessed by sub-second Gd-DTPA enhanced MR imaging. J Comput Assist Tomogr 15:959-965

42. Holman ER, van Jonbergen HP, van Dijkman PR, van der Laarse A, de Roos A, van der Wall EE (1993) Comparison of magnetic resonance imaging studies with enzymatic indexes of myocardial necrosis for quantification of myocardial infarct size. Am J Cardiol 71:1036-1040

43. Buller VG, van der Geest RJ, Kool MD, van der Wall EE, de Roos A, Reiber JH (1997) Assessment of regional left ventricular wall parameters from short axis magnetic resonance imaging using a three-dimensional extension to the improved centerline method. Invest Radiol 32:529-539

44. Bakx AL, van der Wall EE, Braun S, Emanuelsson H, Bruschke AV, Kobrin I (1995) Effects of the new calcium antagonist mibefradil (Ro 40-5967) on exercise duration in patients with chronic stable angina pectoris: a multicenter, placebo controlled study. Ro 40-5967 International Study Group. Am Heart J 130:748-757

45. Portegies MC, Schmitt R, Kraaij CJ et al (1991) Lack of negative inotropic effects of the new calcium antagonist Ro 40-5967 in patients with stable angina pectoris. J Cardiovasc Pharmacol 18:746-751

46. van der Wall EE, Heidendal GA, den Hollander W, Westera G, Roos JP (1980) I-123 labeled hexadecenoic acid in comparison with thallium-201 for myocardial imaging in coronary heart disease. A preliminary study. Eur J Nucl Med 5:401-405

47. de Nooijer R, Verkleij CJ, von der Thüsen JH et al (2006) Lesional overexpression of matrix metalloproteinase-9 promotes intraplaque hemorrhage in advanced lesions but not at earlier stages of atherogenesis. Arterioscler Thromb Vasc Biol 26:340-346

48. Nijveldt R, Beek AM, Hirsch A et al (2008) 'No-reflow' after acute myocardial infarction: direct visualisation of microvascular obstruction by gadolinium enhanced CMR. Neth Heart J 16:179-181

49. Oemrawsingh PV, Mintz GS, Schalij MJ, Zwinderman AH, Jukema JW, van der Wall EE (2003) Intravascular ultrasound guidance improves angiographic and clinical outcome of stent implantation for long coronary artery stenoses: final results of a randomized comparison with angiographic guidance (TULIP Study). Circulation 107: 62-67

50. Ypenburg C, Roes SD, Bleeker GB et al (2007) Effect of total scar burden on contrast-enhanced magnetic resonance imaging on response to cardiac resynchronization therapy. Am J Cardiol 99:657-660
51. Ypenburg C, Sieders A, Bleeker GB et al (2007) Myocardial contractile reserve predicts improvement in left ventricular function after cardiac resynchronization therapy. Am Heart J 154:1160-1165

52. Ypenburg C, van der Wall EE, Schalij MJ, Bax JJ (2008) Imaging in cardiac resynchronisation therapy. Neth Heart $\mathbf{J}$ 16:S36-S40

53. Ypenburg C, Westenberg JJ, Bleeker GB et al (2008) Noninvasive imaging in cardiac resynchronization therapy-part 1: selection of patients. Pacing Clin Electrophysiol 31:1475-1499

54. Ypenburg C, Schalij MJ, Bleeker GB et al (2007) Impact of viability and scar tissue on response to cardiac resynchronization therapy in ischaemic heart failure patients. Eur Heart J 28:33-41

55. Torn M, Bollen WL, van der Meer FJ, van der Wall EE, Rosendaal FR (2005) Risks of oral anticoagulant therapy with increasing age. Arch Intern Med 165:1527-1532

56. van der Laan A, Hirsch A, Nijveldt R et al (2008) Bone marrow cell therapy after acute myocardial infarction: the HEBE trial in perspective, first results. Neth Heart J 16: 436-439

57. Germans T, Wilde AA, van Echteld CJ, Kamp O, Pinto YM, van Rossum AC (2007) Structural abnormalities of the left ventricle in hypertrophic cardiomyopathy mutation carriers detectable before the development of hypertrophy. Neth Heart J 15:161-163

58. Pluim BM, Zwinderman AH, van der Laarse A, van der Wall EE (2000) The athlete's heart: a meta-analysis of cardiac structure and function. Circulation 101:336-344

59. Tops LF, Suffoletto MS, Bleeker GB et al (2007) Speckle tracking radial strain reveals left ventricular dyssynchrony in patients with permanent right ventricular pacing. J Am Coll Cardiol 50:1180-1188

60. Tops LF, Schalij MJ, Holman ER, van Erven L, van der Wall EE, Bax JJ (2006) Right ventricular pacing can induce ventricular dyssynchrony in patients with atrial fibrillation after atrioventricular node ablation. J Am Coll Cardiol 48:1642-1648

61. Roes SD, Mollema SA, Lamb HJ, van der Wall EE, de Roos A, Bax JJ (2009) Validation of echocardiographic two-dimensional speckle tracking longitudinal strain imaging for viability assessment in patients with chronic ischemic left ventricular dysfunction and comparison with contrast-enhanced magnetic resonance imaging. Am J Cardiol 104:312-317

62. Butz T, van Buuren F, Mellwig KP et al (2010) Twodimensional strain analysis of the global and regional myocardial function for the differentiation of pathologic and physiologic left ventricular hypertrophy: a study in athletes and in patients with hypertrophic cardiomyopathy. Int J Cardiovasc Imaging. doi:10.1007/s10554-010-9665-5

63. Faber L, Prinz C, Welge D et al (2010) Peak systolic longitudinal strain of the lateral left ventricular wall improves after septal ablation for symptomatic hypertrophic obstructive cardiomyopathy: a follow-up study using speckle tracking echocardiography. Int $\mathrm{J}$ Cardiovasc Imaging. doi:10.1007/s10554-010-9678-0 